\title{
EVALUATION OF METEOROLOGICAL FACTORS INFLUENCE ON BENZENE ACCIDENTAL POLLUTION. CASE STUDY: BACAU CITY 2008
}

\author{
DOINA CAPSA ${ }^{1 *}$, VALENTIN NEDEFF ${ }^{2,3}$, NARCIS BARSAN ${ }^{2}$, EMILIAN \\ MOSNEGUTU $^{2}$, DANA CHITIMUS ${ }^{2}$ \\ I"Grigore Antipa" National College Bacau, Henri Coanda, 7, Bacau, Romania \\ 2 “Vasile Alecsandri” University of Bacau, Calea Marasesti 157, Bacau, Romania \\ ${ }^{3}$ Academy of Agricultural and Forestry Sciences "Gheorghe Ionescu Sisesti", \\ B-dul. Marasti nr. 61, Sector 1, Bucuresti, Romania
}

\begin{abstract}
Air quality depends on the type and size of industrial activities, traffic intensity, municipal and industrial waste management etc. In addition, air quality in urban areas depends by the green areas management, population density, climatic conditions and geographic. This paper study the correlations between the most important meteorological factors, humidity, temperature, wind and benzene accidental pollution, with influence on pollutant dispersion (related to 2008). The correlation were performed by taken in to considerations the accidental benzene pollution recorded in 2008 in Bacau City and meteorological factor recorded at the regional meteorological station.
\end{abstract}

Keywords: air pollution, benzene, humidity, temperature, wind, climatic factors

\section{INTRODUCTION}

Air quality in urban areas depends in particular on the type and size of industrial activities, the traffic intensity and the waste management. In addition to these, in the analysis of urban air quality is also taken in to account the size and quality of green areas, density of population, geographic and climatological conditions [1-6].

In Bacau City, the air quality is monitored by using continuous automatically measurements, performed using two representative stations positioned in a central area and an industrial area [1-6].

The climatic factors variation influence on the atmospheric pollutants dispersion does not occur only in cases of accidental pollution but also in continuous pollution situations with one or more air pollutants $\left(\mathrm{SO}_{2}, \mathrm{NH}_{3}, \mathrm{NOx}_{\text {, }}\right.$ benzene etc.) [7-9].

The complex analysis of each climatic factor in a specific area can facilitate the evaluation of accidental pollution influence on the air quality in general and the population risk exposed in particular $[1,2,10,11]$.

The literature analyzes also the correlations between climatic factors and atmospheric pollutants from the perspective of the human's health problems (especially the respiratory problems) that can occur [12, 13].

\footnotetext{
* Corresponding author, email: capsadoina@gmail.com

(C) 2017 Alma Mater Publishing House
} 
To establish the links between atmospheric pollutants and climatic factors, the data from a longer period must be analyzed, evaluate their variations, identifying the specificity of the analyzed area, especially if exist some geographic and/ or industrial particularities. Urban areas dimensions are also an important criteria when the air pollutants were analyzed in the climatic factors influence perspective $[1-6,14,15]$.

The analysis of air quality in an urban area is in correlation with its industrial specificity, but the analysis of climatic factors mainly involves the variations of air temperature and humidity, wind speed and precipitation [15, 16].

The air quality monitoring factors is carried out within the legal regulations established by the European directives and by their implementation at national level [17-22].

In this study the meteorological elements analyzed and correlated with variations of the benzene concentration were: air temperature, atmospheric pressure, atmospheric humidity, solar radiation, wind speed and direction.

\section{EXPERIMENTAL SETUP}

\subsection{Air quality measurement in Bacau}

There are two urban air quality monitoring stations in Bacau, one located in the center of the city, behind the Prefecture building (overall image Figure 1) and, the other in the Izvoare district (an industrial area). These stations were put into function in 2008, until this date, the air quality monitoring was performed manually (Figure 2).

The monitored pollutants, measurement methods, limit values, alert and information thresholds are controlled by national legislation and comply with the European regulations requirements transposed into national legislation by Order no. 592 of June 25, 2002, Law no. 104 of 15 June 2011 regarding ambient air quality. The data recorded values were compared with 12574/87 Regulation - Air Quality Conditions in Protected Areas [19-21].

Considering the urban position of the Bacau 1 air quality monitoring stations (BC1) and the importance of the air monitoring in the high populated area in this study only the benzene variation value from $\mathrm{BC} 1$ was evaluated.

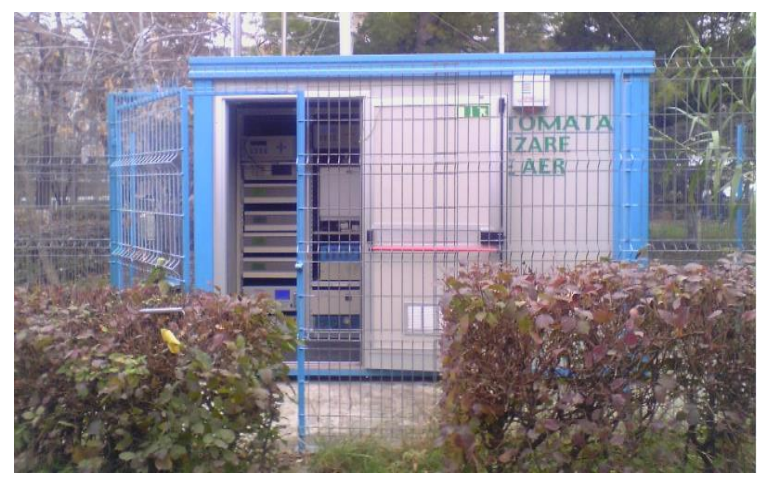

Fig. 1. BC1 air quality monitoring station.

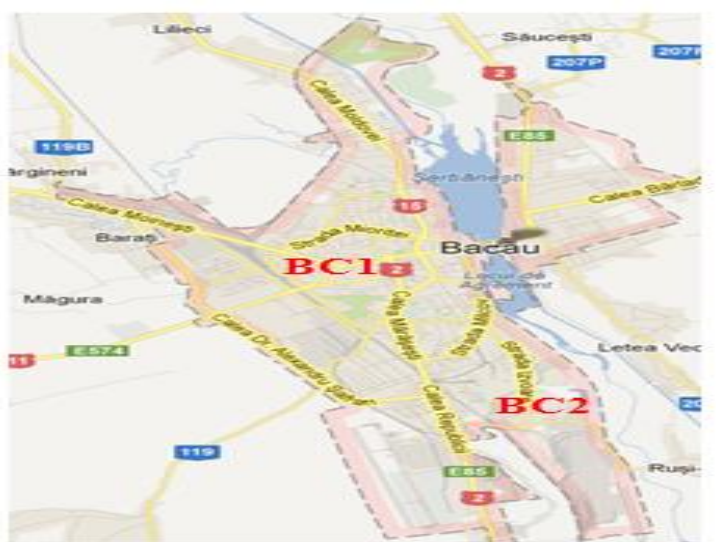

Fig. 2. BC1 and BC2 stations mapping points [1].

The benzene pollutant was measured by stations according with SR EN 14662 [22]. Benzene is a hydrocarbon having a high chemical stability, which solidifies at $5.5^{\circ} \mathrm{C}$ and boils at $80{ }^{\circ} \mathrm{C}$. This involves a long remanence, in the limit of the troposphere, where it can accumulate. Benzene is removed from the atmosphere by the phenomenon of dispersion under specific weather conditions or by photochemical reactions. Studies and research into the effect of benzene on the environment and human health has led to the idea that it is dangerous for chemical industry workers, gas stations, car service, and also for people situated in the high traffic areas.

\subsection{Climatological aspects of Bacau city}

Bacau city is situated in the North-East of Romania, $46^{\circ} 35^{\prime} \mathrm{N}, 26^{\circ} 55^{\prime} \mathrm{E}$. The city represent a complex geographical area with many specific particularities. The tall mountainsides from the left banks of the Siret River 
are interrupted by terraces and the mountainsides from the right part of the river are smaller and present long terraces.

Bacau is situated at $9.6 \mathrm{~km}$ from the upstream confluence of Siret and Bistrita Rivers at an altitude of $160.056 \mathrm{~m}$ [23]. The common valleys of the two rivers form a depressionary corridor with a North-South orientation. The junction area and the Bistrita river corridor determine some specific air channeling as effect of the predominant wind direction from the South and South-East.

The climate is temperate-continental, specific for the region of Moldavia, with influences of the complex and sometimes devastating of the natural and the atrophic factors [24].

The presence of the junction area and the corridor of the Bistrita River channel the air during meteorological conditions characterized by winds from the South and South-East directions, alternating with calmness periods (medium speed of the wind $<1.5 \mathrm{~m} / \mathrm{s}$ ) are the determined conditions for the temperatures inversion situations. These inversions of temperatures (situations in which a layer of cold air is under a layer of warm air) may appear in a stationary atmospheric front of high pressure combined with reduced speed of the wind. In these conditions the atmospheric chemical combinations between air and polluting substances slow down, as well as the reducing processes and the polluting elements gather at low altitudes, close to the soil surface.

\section{RESULTS AND DISCUSSION}

In the analysis of meteorological parameters influence in to benzene dispersion or accumulation were considered the minimum concentration value exceeded for 8 hours period.

The first day of benzene pollutant value exceeding evaluation was 10.20.2008. The above graphics put in to correlation benzene value concentration with: temperature and atmospheric pressure (Figure 3), air humidity and solar radiation (Figure 4), wind speed and direction (Figure 5) [1].

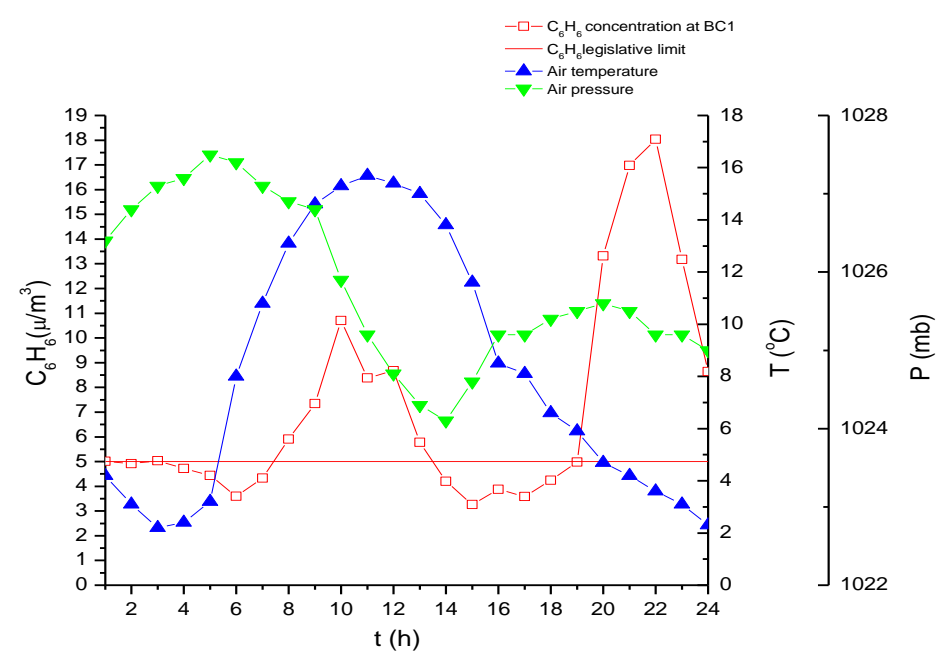

Fig. 3. Air benzene concentration variation, air temperature $(\mathrm{T})$ and atmospheric pressure $(\mathrm{P})$ over 24 hours, on October 20, 2008 at the Bacau Air Quality Monitoring Station (BC1).

From the benzene concentration analysis, recorded at BC1 quality monitoring station on October 20, 2008, correlated with the studied meteorological parameters can be put into discussion some aspects [1]:

- Over 24 hours the benzene concentration exceeded the limit values in fourteen hours interval, with a maximum value of $18.04 \mu \mathrm{g} / \mathrm{m}^{3}$ at 22.00 , which corresponds to an 3.68 excess of the allowable limit and the other to 10.00 hours period, with a maximum value of $10.70 \mu \mathrm{g} / \mathrm{m}^{3}$, which corresponds to an 2.14 times excess.

- The atmospheric pressure fell with $2.3 \mathrm{mb}$ at 14.00 , then remained high throughout the day, showing variations of \pm 1 around $1025 \mathrm{mb}$.

- $\quad$ Air temperature and solar radiation showed a strong daily increase. 
- From the humidity point of view, the air can be characterized as being very damp from the first hours of the day to the sunrise and then after sunset, in the rest of the day the air can be characterized as being hydrometrically dry;

- $\quad$ The sky was variable until clear, cloudy in the afternoon, and the wind was generally calm.

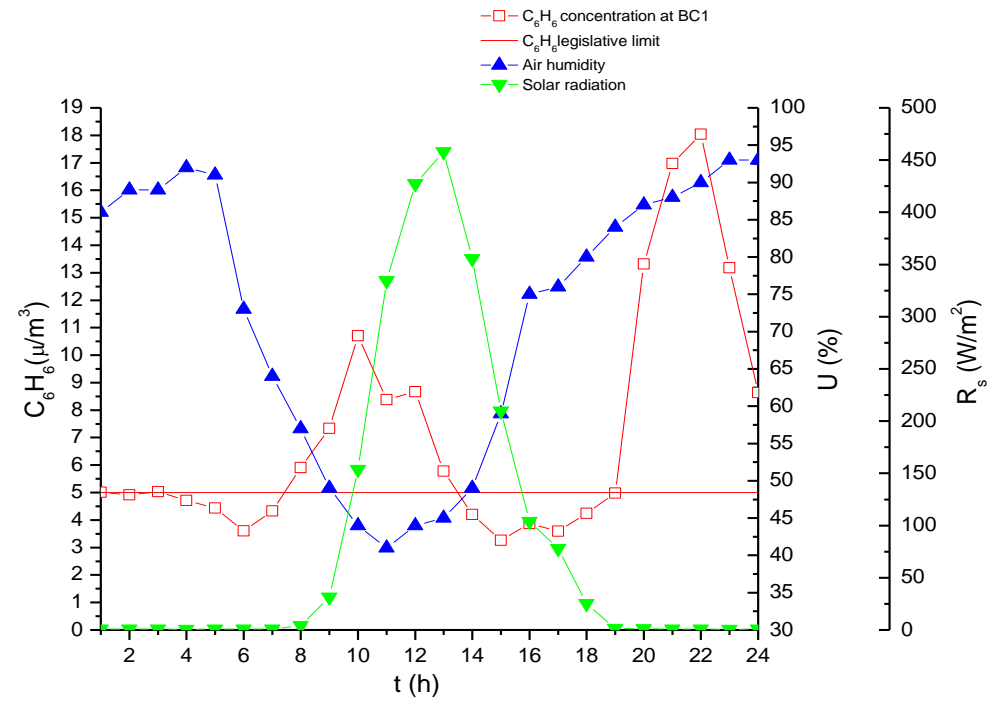

Fig. 4. Air benzene concentration variation, air humidity $(\mathrm{U})$ and solar radiation $\left(\mathrm{R}_{\mathrm{S}}\right)$ over 24 hours, on October 20, 2008 at the Bacau Air Quality Monitoring Station (BC1).

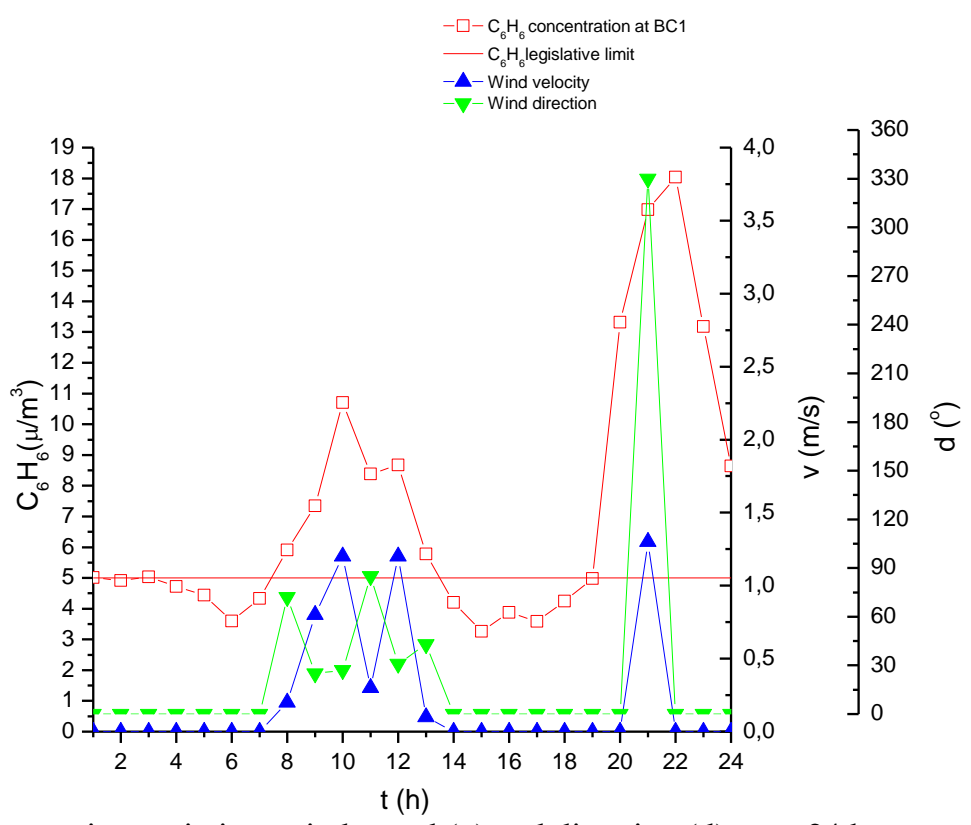

Fig. 5. Air benzene concentration variation, wind speed (v) and direction (d) over 24 hours, on October 20, 2008 at the Bacau Air Quality Monitoring Station (BC1).

In the other evaluation we can interpreted that the weather with climatically normal thermal values for this period, benzene dispersion was achieved when the first peak was recorded over six hours interval. Weak wind and high temperatures were not favorable for dispersion. In the second case, on a high heat background, because of the slight increase of the wind in the northern sector to an average of $1.3 \mathrm{~m} / \mathrm{s}$, and the maintenance of a high atmospheric pressure, benzene dispersion achieved in the same range while the maximum reached was 3.68 times higher. 
Another exceedance of the allowed limit for benzene concentration was registered at the $\mathrm{BC} 1$ air quality monitoring station on 21.10.2008 (Figure 6, 7 and 8) [1].

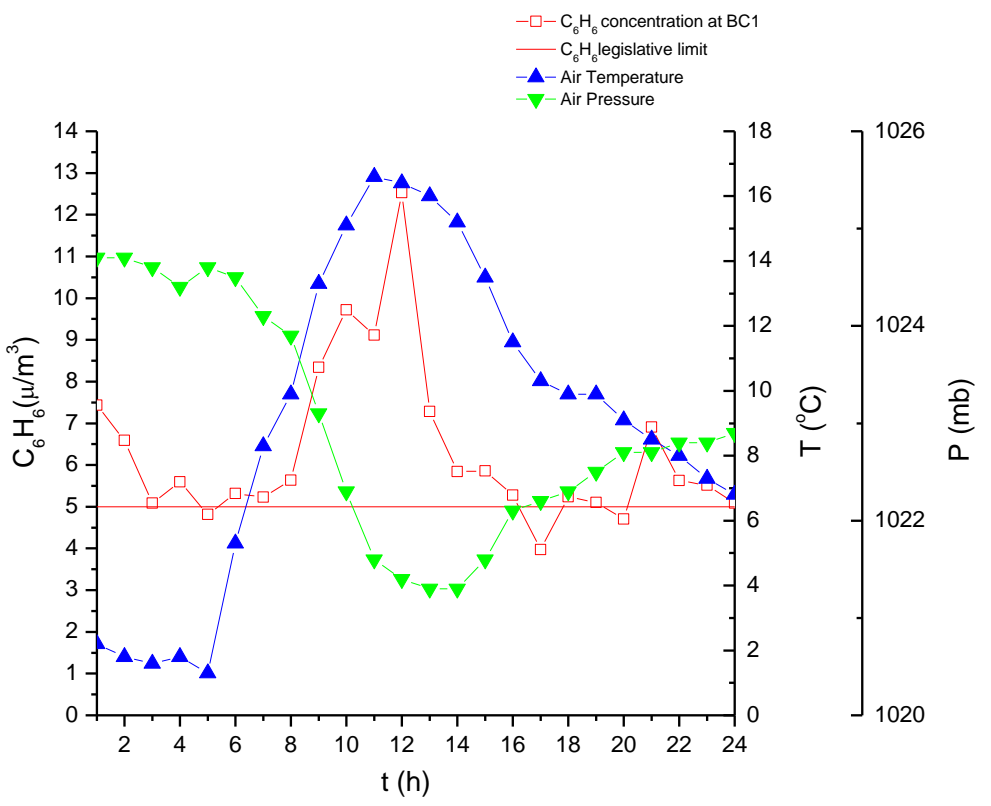

Fig. 6. Air benzene concentration variation, air temperature (T) and atmospheric pressure (P) over 24 hours, on October 21, 2008 at the Bacau Air Quality Monitoring Station (BC1).

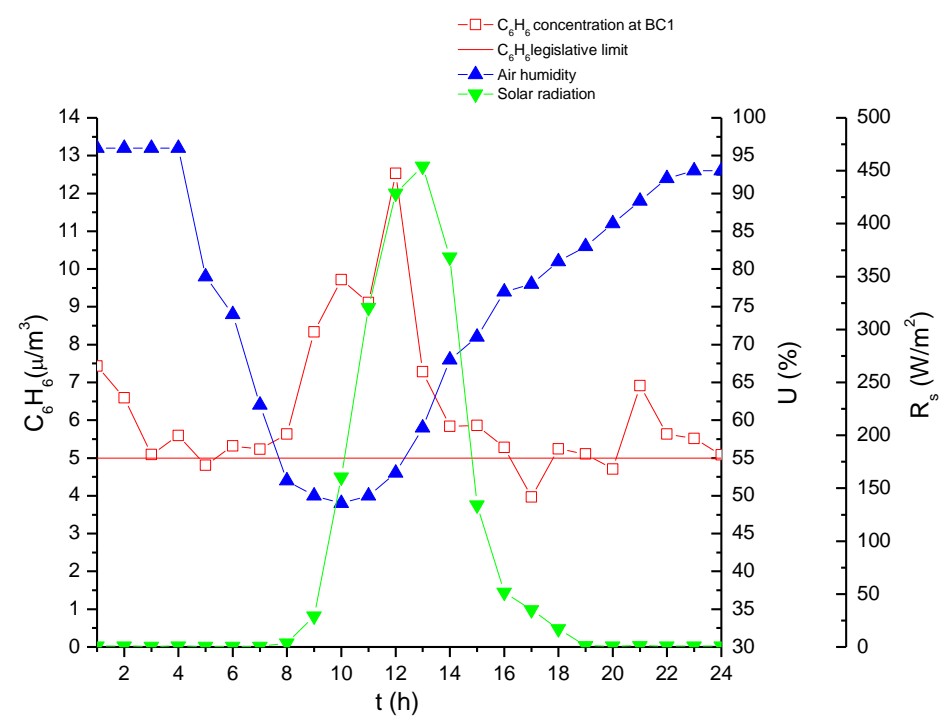

Fig. 7. Air benzene concentration variation, air humidity $(\mathrm{U})$ and solar radiation $\left(\mathrm{R}_{\mathrm{S}}\right)$ over 24 hours, on October 21, 2008 at the Bacau Air Quality Monitoring Station (BC1).

The benzene value variation correlated with meteorological parameters led to the following interpretation [1]:

- In 24 hours was recorded benzene concentration exceed over a period of 21 hours with a maximum of $12.52 \mu \mathrm{g} / \mathrm{m}^{3}$ at 12.00 which corresponds to an excess of 2.5 times the allowable limit;

- The atmospheric pressure decreased by $3.1 \mathrm{mb}$ from $1025.2 \mathrm{mb}$ to $1022.1 \mathrm{mb}$ at 15.00 , then increase with $1 \mathrm{mb}$;

- $\quad$ Air temperature and solar radiation marked an increase during daytime;

- After humidity analyzing it can be seen that the air can be characterized as being very damp until 10.00 am and the air can still be characterized as hygrometric normal;

- The sky was variable until clear, and the wind was calm until 10.00, then intensified from the southern sector at medium speeds of up to $3.6 \mathrm{~m} / \mathrm{s}$. 
Pollutant dispersion was favored by lowering of temperature, slight pressure increase and normal atmospheric humidity.

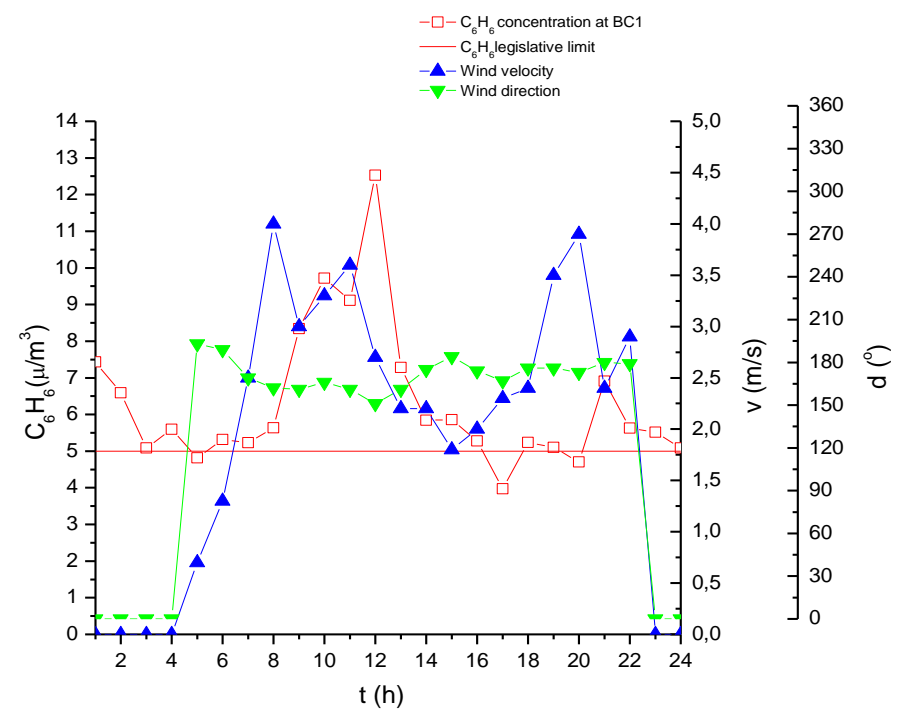

Fig. 8. Air benzene concentration variation, wind speed (v) and direction (d) over 24 hours, on October 21, 2008 at the Bacau Air Quality Monitoring Station (BC1).

Another exceedance of the allowed limit for benzene concentration was recorded at the $\mathrm{BC} 1$ air quality monitoring station (Prefecture) on 10.23.2008 (Figure 9, 10 and 11). This variation correlated with meteorological parameters led to the following interpretation [1]:

- In 24 hours there was a modification of benzene concentration over nine hours when a maximum of $16.40 \mu \mathrm{g} / \mathrm{m}^{3}$ was reported at 21.00 , which corresponds to a 3.28 increase over the admissible limit;

- The atmospheric pressure oscillating around $1024 \mathrm{mb}$ until 19.00 then marked an increase of $4 \mathrm{mb}$ to $1028 \mathrm{mb}$;

- $\quad$ The air temperature and solar radiation present a normal daily increase;

- $\quad$ From the humidity point of view, the air can be characterized as normal from a hygrometric point of view until 18.00 , then gradually becomes wet to saturate;

- $\quad$ The sky was variable until clear until 18.00;

- The wind was weak to moderate from the South-East sector until 21:00, then the direction modify from the northern sector and increased to $5.9 \mathrm{~m} / \mathrm{s}$.

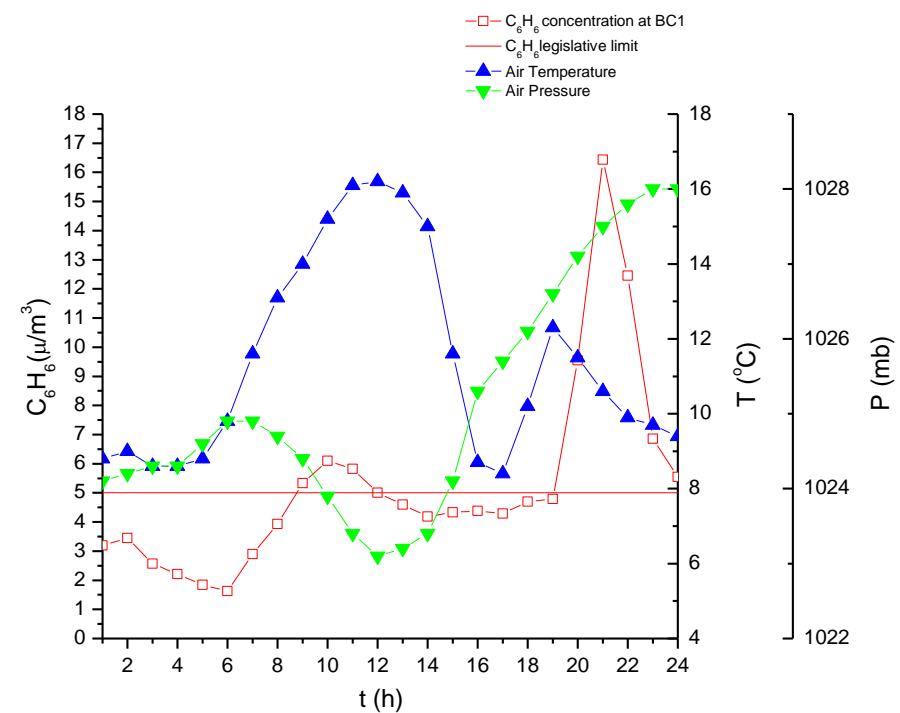

Fig. 9. Air benzene concentration variation, air temperature $(\mathrm{T})$ and atmospheric pressure $(\mathrm{P})$ over 24 hours, on October 23, 2008 at the Bacau Air Quality Monitoring Station (BC1). 


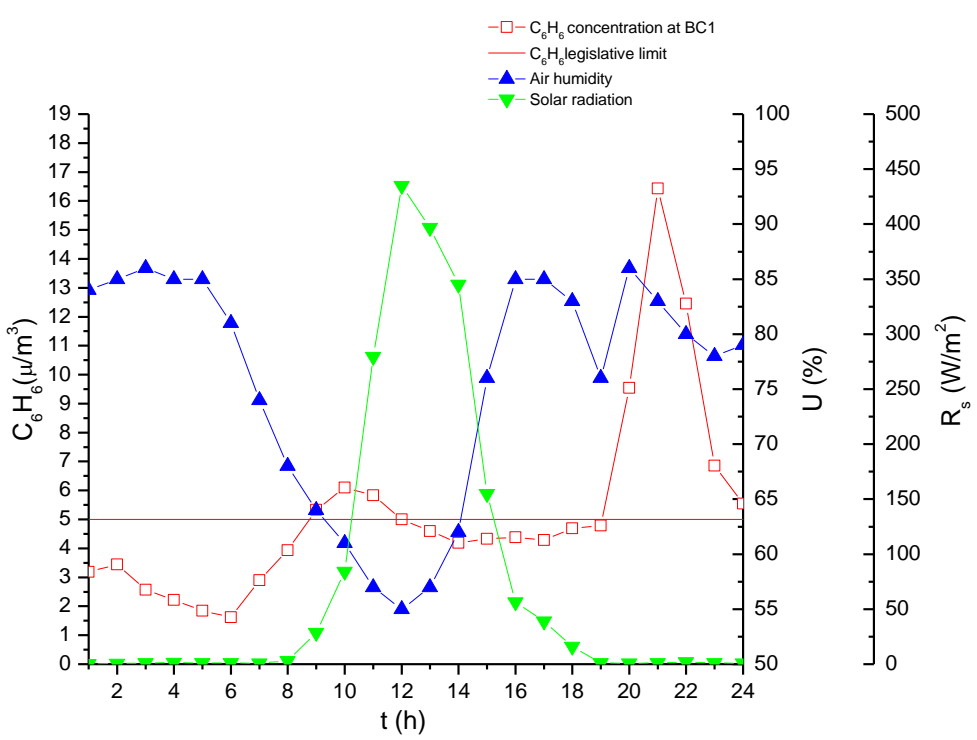

Fig. 10. Air benzene concentration variation, air humidity $(\mathrm{U})$ and solar radiation $\left(\mathrm{R}_{\mathrm{S}}\right)$ over 24 hours, on October 23, 2008 at the Bacau Air Quality Monitoring Station (BC1).

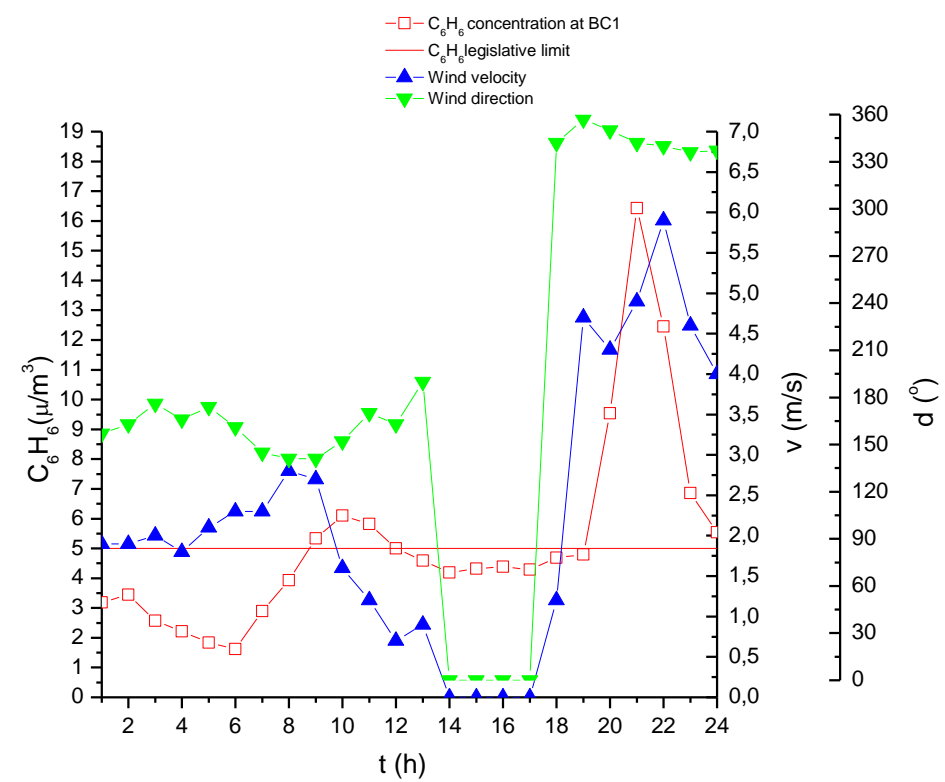

Fig. 11. Air benzene concentration variation, wind speed (v) and direction (d) over 24 hours, on October 21, 2008 at the Bacau Air Quality Monitoring Station (BC1).

The benzene pollutant dispersion was influenced by air pressure increase. Also the wind velocity increases from Nordic direction and the air temperature and atmospheric humidity decrease.

\section{CONCLUSIONS}

By correlating the climatic factors variation with the benzene pollutant values, measured in 2008, it can be said that the exceeding of the limit value for this pollutant corresponds to the following meteorological conditions:

- $\quad$ The air temperature values were above the climatological norm of the period, and the solar radiation had a low values;

- $\quad$ The recorded atmospheric pressure were high values compared to normal;

- Atmospheric humidity can characterize the air as wet to saturate, and the wind was in generally weak from southern direction. 


\section{REFERENCES}

[1] Capsa, D., Studii si cercetari privind variatia calitatii mediului industrial în corelatie cu factorii climatici, Teza de doctorat, Universitatea "Vasile Alecsandri" din Bacau, 2015.

[2] Ciulache, S., Meteorologie si climatologie, Editura Universitara, Bucuresti, 2004.

[3] Capsa, D., Barsan, N., Nedeff, V., Mosnegutu, E., Chitimus, D., Evaluation of the ammonia air pollution and climatic factors interactions, case study 2008 Bacau City Romania, Journal of Engineering Studies and Research, vol. 22, no. 1, 2016, p. 24-31.

[4] Capsa, D., Panainte, M., Chitimus, D., Stanila, M., Felegeanu, D.C., Accidental pollution with ammonia. Influence of meterological factors, Environmental Engineering and Management Journal, vol.13, no.7, 2014, p.1573-1580.

[5] Capsa, D., Nedeff, V., Vasilica, M., Lazar, G., Panainte, M., Barsan, N., Extreme temperatures and their effects on the human body Present Environment and Sustainable Development, vol. 6, no. 2, 2012, p. 387-404.

[6] Capsa D., Nedeff V., Barsan N., Climatic factors influences to the ammonia air pollution, case study 2009 Bacau city Romania, The Academic Journal of Science, vol. 2 no. 9, 2014.

[7] Cisneros, R., Bytnerowicz A., Schweizer D., Zhong S., Traina S., Bennett D., Ozone, nitric acid, and ammonia air pollution is unhealthy for people and ecosystems in southern Sierra Nevada, California, Environmental Pollution, no. 158, 2010, p. 3261-3271.

[8] Wangpattarapong, K., Maneewan, S., Ketjoy, N., Wattanapong Rakwichian, The impacts of climatic and economic factors on residential electricity consumption of Bangkok Metropolis, Energy and Buildings vol. 40, 2008.

[9] Munn, R. E., Air Pollution Meteorological, http://whqlibdoc.who.int/ euro/es/ EURO_SERIES_1_(chp7).pdf, (17.03.2012).

[10] Murena, F., Vorraro, F., Vertical gradients of benzene concentration in a deep street canyon in the urban area of Naples. Atmospheric Environment, vol. 37, 2003, p. 4853-4859.

[11] Tanase, I., Clima Podisului Sucevei - fenomene de risc, implicatii asupra dezvoltarii durabile, Teza de doctorat, Universitatea „Stefan cel Mare”, Suceava, 2009.

[12] Paraschiv, V., Miron Machidon, O., Capsa, D,. Gaina, J., Climatic and hydrological hazards in june 26-27, 2010 in the upper basin of Trotus. case study: between the proposed preparation and the effects at Agas (county of Bacau), Present Environment and Sustainable, Development, vol. 8, 2014.

[13] Seinfeld, J.H., Atmospheric Chemistry and Physics of Air Pollution, John Wiley \&Sons, New York, 1992.

[14] Perrone, M.G., Larsen, B.R., Ferrero, L., Sangiorgi, G., Gennaro, G. De, Udisti, R., Zangrando, R., Gambaro, R. A., Bolzacchini, E., Sources of high PM2.5 concentrations in Milan, Northern Italy: Molecular marker data and CMB modelling, Science of The Total Environment, vol. 414.0, 2012, p. 343-355.

[15] Stefan, S., Fizica atmosferei, Bucuresti, Editura Universitatii din Bucuresti, 2004.

[16] Ayoe, G., Hansen, B., Jericevic, A., Prank, M., Segersm, A., Silver, J.D., Werhahn, J., Wolke, R., Rao, S.T., Galmarini, S., Evaluation of the meteorological forcing used for the Air Quality Model Evaluation International Initiative (AQMEII) air quality simulations, Atmospheric Environment, 2011, p.1-23.

[17] Mihaila, D., Meteorologie si Climatologie, Curs multiplicat destinat învatamantului la distanta, la Universitatea „Stefan cel Mare”, Suceava, 2008.

[18] Zhoua, Y., Brunnera, D., Hueglina, C., Hennea, S., Staehelin, J., Changes in OMI tropospheric NO2 columns over Europe from 2004 to 2009 and the influence of meteorological variability, Atmospheric Environment, vol. 46, 2012, p. 482-495.

[19] Guvernul Romaniei, Legea nr.139 din 24 iulie 2000 privind activitatea de meteorologie, 2000.

[20] Guvernul Romaniei, Standard de Stat 12574-87, privind aerul din zonele protejate, 1987.

[21] Legea nr. 104/2011 privind calitatea aerului înconjurător.

[22] SR EN 14662 Ambient air quality - Standard method for measurement of benzene concentrations - Part 1: Pumped sampling followed by thermal desorption and gas chromatography.

[23] Capsa D., Nedeff V., Faciu E., Lazar G., Lazar I., Barsan N., Aspects of the fog phenomenon in Bacau city, Present Environment and Sustainable, Development, vol. 6, no.1, 2012, p. 325 - 340.

[24] Vasilica, M., Capsa, D., Covac,i I., Nedeff, V., Barsan N., Panainte, M., Case study on heavy rainfall in the central-southern Moldavia Regional Romania, Environmental engineering and management journal, 11, 2012, p. 2151-2158. 